\title{
THE VERTICAL LOAD CARRYING CAPACITY OF THE COLUMNS OF MULTI-STORY REINFORCED CONCRETE FRAMES WITH THE EXPERIENCE OF HORIZONTAL LOADING
}

\author{
by TAKAYUKI SHIMAZU* and S. M. PARVEZ MOHIT**, \\ Members of A. I. J.
}

\section{Introduction}

It has been recognized from various earthquake experiences as well as the results of structural analysis that weak-beam, strong-column type of frames is suitable for aseismic design of buildings because in this type of frames, total deformation at the top of buildings induced by earthquakes can be distributed to a considerable extent uniformly along the height of buildings.

Owing to this desirable trend of uniform deformation, maximum interstory drift of this type of frames will be much smaller even for major earthquakes than that of strong-beam, weak-column type of frames. Furthermore residual interstory drift after earthquakes may also be very small.

However, there will be much possibility of danger in the continuation of the use of the reinforced concrete buildings consisting of such type of frames after earthquakes because the beams of frames have already much softened regions at the ends inspite of little evidence of damage caused by earthquakes in appearance, due to the restoring force characteristics of reinforced concrete.

Questions arise on the structural safety of such type of frames against vertical loads after earthquakes. How is the column stability? How much is the vertical load carrying capacity of beams? And what about the time-dependent deformation of beams? etc.

However, the philosophy of structural design of weak-beam, strong-column frames has not yet been established until very recently. So there seems to be no literature on the studies done to answer these questions up to date, though the studies ${ }^{1)-3}$, has been reported on the stability of single story frame columns.

Experimental study has been initiated in our laboratory with an aim to answer these questions and to propose appropriate design methods of weak-beam, strong-column type of frames, taking into account the vertical resistance after earthquakes.

This paper presents the one of a series of studies on the vertical resistance of reinforced concrete frames with the experience of horizontal loading. In this paper focus is placed on the problem of column stability.

The philosophy of limit design method is also introduced into structural design of frames to replace the currently used elastic design methods.

In the next Section, the equations are derived for estimating the vertical load carrying capacity of the columns of multi-story reinforced concrete frames with the experience of high level of horizontal loading upto post-yielding range. Following this derivation of the equations, the experimental works are presented to verify the validity of them.

The abstract of this paper was already reported in Ref. 4.

\section{Derivation of the Equations}

It seems that it involves much difficulty to find out the solution for the stability problem of the columns of

\footnotetext{
* Professor, University of Hiroshima, Dr. of Eng.

** Graduate Student, University of Hiroshima, Mr. of Eng.

Manuscript received March 11, 1985
} 
multi-story frame with the experience of horizontal loading because the behaviour of reinforced concrete frame become already much complicated when subjected to horizontal load upto the inelastic range. However, in this paper the energy method on elastic stability ${ }^{5}$ is used for the solution of this problem by paying attention to the restoring force characteristics of reinforced concrete members, which can approximately be assumed to be of origin oriented type with degrading stiffness. It become easier to use this method for weak-beam, strong-column frame already subjected to horizontal load upto post-yielding range as explained below.

The expression for the strain energy of bending for the system as shown in Fig. 1 becomes

$$
U=\frac{1}{2} \int_{0}^{H}\left(E I_{x}\right) \cdot\left[\frac{d^{2} y^{2}}{d x^{2}}\right]^{2} \cdot d x
$$

The decrease in the potential energy of the vertical load due to the lowering of the point of application of the load and the work done by the bending moment at each beam end becomes

$$
U_{1}=\frac{1}{2} \int_{0}^{H} \sum_{i}^{n} q_{i} \cdot\left[\frac{d y}{d x}\right]^{2} \cdot d x+\frac{1}{2} \sum_{i=1}^{n} M_{i} \cdot \theta_{i}
$$

The critical value of the compressive force is obtained from the condition

$$
U=U_{1}
$$

Beams of the frames may be assumed to be subjected to anti-symmetrical bending at the starting of instability under vertical load. With the axes taken as indicated in Fig. 1, the bending moment at any cross section becomes $\sum_{i}^{n} q_{i} \cdot\left(\delta_{i}-y\right)-\sum_{i}^{n} M_{y_{i}}$ and the differential equation of the deflection curve is

$$
E I_{x} \cdot \frac{d^{2} y}{d x^{2}}=\sum_{i}^{n} q_{i}\left(\delta_{i}-y\right)-\sum_{i}^{n} M_{i}
$$

The following assumptions were made for the weak-beam, strong-column frame with the experience of horizontal loading upto post-yielding range.

1) All the beam ends yield and so the rotational stiffness is

$$
K_{\theta i}=M_{y i} / \theta_{\max i}
$$

in which $M_{y i}$ is the yield strength and can be calculated with $0.9 \cdot A_{i} \cdot \sigma_{y} \cdot d$ according to R. C. Code of AIJ ${ }^{6)}$ and $\theta_{\max i}$ is the value of the maximum rotation angle of each beam, under horizontal load as shown in Fig. 2 (a) and (b).

2) The cross section of column is assumed uniform along the overall height. The equivalent flexural rigidity $(E I)_{e q}$ of columns is evaluated based on the restoring force characteristics of columns as will be explained in the Section 5 .

The next step is how to assume the deflection curve of the column when under the action of a compressive load. The general expression for the deflection curve of a column with fixed end can be represented by the series

$$
y=\Delta_{1}\left[1-\cos \frac{\pi x}{2 H}\right]+\Delta_{2}\left[1-\cos \frac{3 \pi x}{2 H}\right]+\cdots \cdots+\Delta_{k}\left[1-\cos \frac{(2 k-1) \pi x}{2 H}\right] \cdots
$$

However, it usually involves much difficulty to get the solution by using this series for the highly statical indeterminate structure. In this paper the following deflected shape was assumed, taking into account that horizontal loading made first-order mode for the frames.

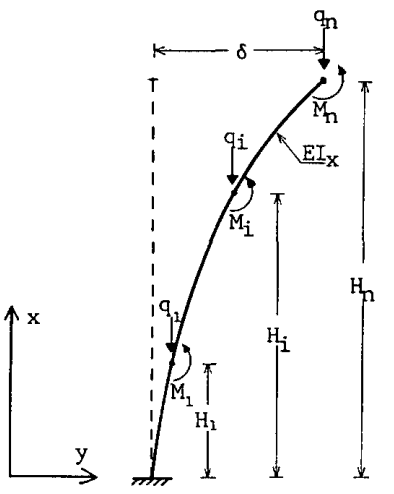

Fig. 1 Frame model for vertical load analysis

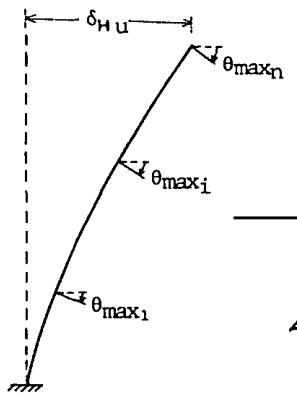

(a)

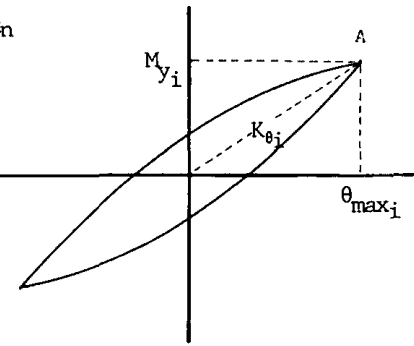

(b)

Fig. 2 Assumed equivalent rotational stiffness, $K_{\theta i}$ 


$$
y=\delta \cdot\left[\frac{x}{H}\right]^{m}
$$

The solution can be obtained by selecting the value of $\mathrm{m}$ so as to make the critical load a minimum.

In general vertical loads are transmitted from beams to columns at each floor. The following equation can be obtained for vertical load carrying capacity of $n \cdot q_{c r}$ by assuming the deflected shape of Eq. 7 when equally distributed loads are applied at each floor for uniform story height frame.

$$
a \cdot q_{c r}^{2}+b \cdot q_{c r}+c=0
$$

where,

$$
\begin{aligned}
& a=\sum_{j=1}^{n}\left[\frac{1}{n}\left\{\sum_{i \geq j}^{n}\left[\frac{i}{n}\right]^{m}\right\}^{2}-2 \cdot \sum_{i \geq j}^{n}\left[\frac{i}{n}\right]^{m} \cdot \frac{1}{m+1}\left\{\left[\frac{j}{n}\right]^{m+1}-\left[\frac{j-1}{n}\right]^{m+1}\right\}\right. \\
& \left.+\frac{1}{2 m+1}\left\{\left[\frac{j}{n}\right]^{2 m+1}-\left[\frac{j-1}{n}\right]^{2 m+1}\right\}\right] \\
& b=-\frac{2 m}{H} \cdot \sum_{j=1}^{n}\left[\left\{\frac{1}{n} \sum_{i \geq j}^{n}\left[\frac{i}{n}\right]^{m}-\frac{1}{m+1}\left(\left[\frac{j}{n}\right]^{m+1}-\left[\frac{j-1}{n}\right]^{m+1}\right)\right\}\right. \\
& \left.\cdot \sum_{i \geq j}^{n} K_{\theta i} \cdot\left[\frac{i}{n}\right]^{m-1}\right]-\frac{m^{2}(E I)_{e q}}{(2 m-1) H^{2}} \cdot \sum_{i=1}^{n}\left[\frac{i}{n}\right]^{2 m-1} \\
& c=\frac{m^{2}}{H^{2}} \cdot\left[\sum_{j=1}^{n} \frac{1}{n}\left\{\sum_{i \geq j}^{n} K_{\theta i} \cdot\left[\frac{i}{n}\right]^{m-1}\right\}^{2}-\frac{(E I)_{e q}}{H} \sum_{i=1}^{n} K_{\theta i} \cdot\left[\frac{i}{n}\right]^{2 m-2}\right] .
\end{aligned}
$$

The vertical load carrying capacity $W_{c r}$ can also be obtained as follows when concentrated loads instead of distributed loads are applied at the top for uniform story height frame as explained in the next Section.

$$
a \cdot W_{c r}^{2}+b \cdot W_{c r}+c=0
$$

where,

$$
\begin{aligned}
& a=1-\frac{2}{m+1}+\frac{1}{2 m+1} \\
& b=-\frac{2 m}{H} \cdot \sum_{j=1}^{n} \cdot\left[\sum_{i \geq j}^{n} K_{\theta i} \cdot\left[\frac{i}{n}\right]^{m-1}\left\{\frac{1}{n}-\frac{1}{m+1}\left[\frac{j}{n}\right]^{m+1}+\frac{1}{m+1}\left[\frac{j-1}{n}\right]^{m+1}\right\}\right]-\frac{m^{2}(E I)_{e q}}{(2 m-1) H^{2}} \\
& c=\frac{m^{2}}{n H^{2}} \cdot \sum_{j=1}^{n}\left\{\sum_{i \geq j}^{n} K_{\theta i} \cdot\left[\frac{i}{n}\right]^{m-1}\right\}^{2}-\frac{m^{2}(E I)_{e q}}{H^{3}} \cdot \sum_{i}^{n} K_{\theta i} \cdot\left[\frac{i}{n}\right]^{2 m-2}
\end{aligned}
$$

On the other hand, the vertical load carrying capacity for the frames subjected to vertical load only can be calculated using the following cummulative strength equation on axial compression strength ${ }^{\text {?) }}$.

$$
W_{c r}=A_{c} \cdot F_{c}+A_{s} \cdot \sigma_{y}
$$

\section{Test Programme}

The specimens used for this study were single-bay, multi-story reinforced concrete frames. A typical model

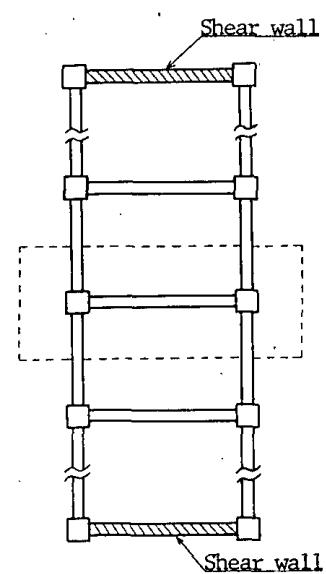

Fig. 3 A single-bay, multi-story reinforced concrete building plan with the location of the interior frame, used as the test specimen

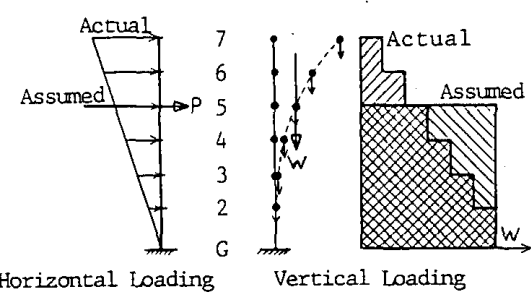

Fig. 4 Assumptions for the point of application of loadings

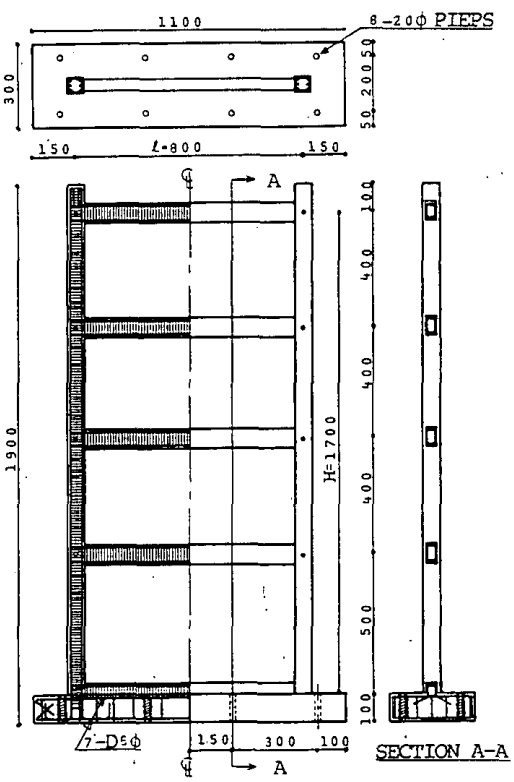

Fig. 5 The specimen with reinforcement (C $63-42 \mathrm{H})$ 
specimen ( $\mathrm{C}$ 63-42 H) was supposed to represent a six-storied frame, one of the single-bay frames in rows as shown in Fig. 3. However, the number of stories of the specimens was reduced to four for the simplicity of the application of loads. Fig. 4 explains why this reduction of the numbers of the stories was made. The effects of this reduction, that are the relations between the models and the prototypes will be discussed quantitatively later in this Section. Fig. 5 shows the overall dimension and the reinforcement of specimen ( $\mathrm{C} 63-42 \mathrm{H}$ ). The calculated maximum shear coefficient at collapse mechanism under horizontal loading was 0.07 for this weak-beam, strong-column specimen with axial force level of $0.2 F_{\mathrm{c}} b D$ for columns. The value of 0.07 is increased to 0.09 when the upper two more beams are considered. Usually shear walls are allotted to resist about two-third of total shear. Thus the building including this frame can be assumed to resist lateral force of about $30 \%$ of gravity load.

Stirrups and hoops were provided to ensure sufficient ductility, according to the R. C. Code of AIJ. The number of specimens totaled eight. Out of which, six were four-storied and the other two were two-storied frames. Table 1 shows the dimensions and the cross section properties of all the eight specimens. The first two specimens were designed basically in accordance with the currently used methods in such a way that the strength of beams was allotted smaller for upper stories and greater for lower stories. Particularly the difference of strength between the upper and lower stories for this frame was made greater than that of prototype to see the effects distinctly as shown in Table 2. On the other hand the other six specimens were designed according to the limit design method in the way that the strength of beams was arranged uniformly along the height with total value of strength being the same as in the above first type of frames for four-storied ones. Table 3 shows the calculated results of vertical load carrying capacity obtained by using Eq. ( 8 ) and Eq. (12) for both the models (specimens) and the prototypes vith the changing value of each variable. The effects of the equivalent flexural rigidity $(E I)_{e q}=a_{v} \cdot E I$ of columns, beam end rotational stiffness $K_{\theta i}$ and the deflected shape (for $\theta_{\max i}$ ) are shown with two values for each case.

Table 1 Cross section properties of members of specimens

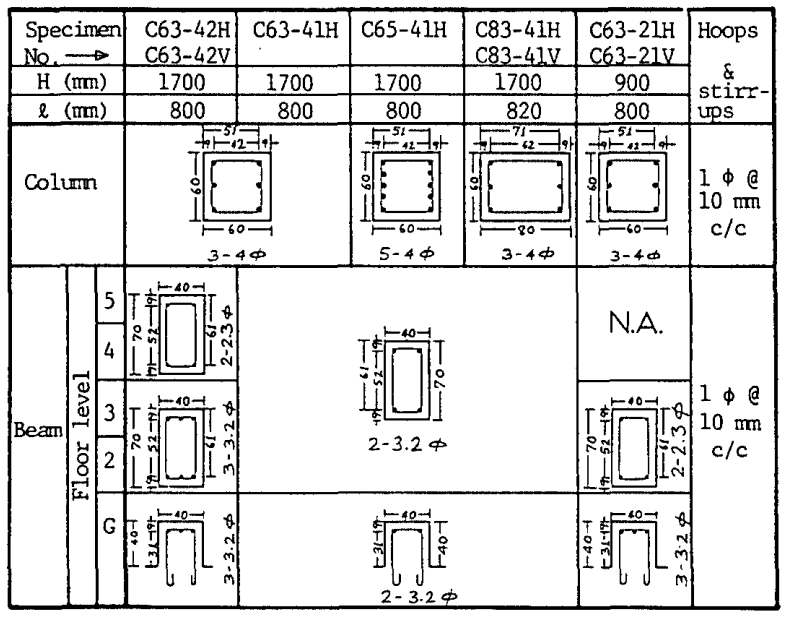

Table 2 Comparison of beam strength ratios between prototypes and models

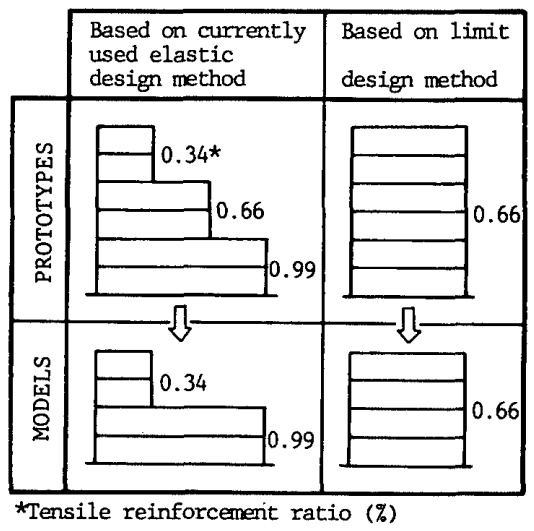

Table 3 Comparison of calculated vertical load carrying capacities between models and prototypes having the experience of reversed horizontal loadings

\begin{tabular}{|c|c|c|c|c|c|c|c|c|c|}
\hline & \multicolumn{4}{|c|}{$\alpha_{v}=1 / 3$} & \multicolumn{4}{|c|}{$\alpha_{v}=2 / 3$} \\
\hline & & \multicolumn{2}{|c|}{$y=\delta \cdot\left(\frac{x}{H}\right)^{2}$} & \multicolumn{2}{|c|}{$y=\delta \cdot \frac{x}{H}$} & \multicolumn{2}{|c|}{$y=\delta \cdot\left(\frac{x}{h}\right)^{2}$} & \multicolumn{2}{|c|}{$y=\delta \cdot \frac{x}{H}$} \\
\hline & & $\mathrm{K}_{\theta_{i}}=\frac{\mathrm{My}_{i}}{\theta_{\max _{i}}}$ & $\mathrm{~K}_{\theta_{i}}=\frac{2 \mathrm{My}_{i}}{\theta_{\max }}$ & $\mathrm{K}_{\theta_{i}}=\frac{M_{y_{i}}}{\theta_{\max }}$ & $\mathrm{K}_{\theta_{i}}=\frac{2 \mathrm{My}_{i}}{\theta_{\max }}$ & $K_{\theta_{i}}=\frac{M y_{i}}{\theta_{\max }}$ & $K_{\theta_{i}}=\frac{2 M_{j}}{\theta_{\max }}$ & $K_{\theta_{i}}=\frac{M y_{i}}{\theta_{\max }}$ & $K_{s_{i}}=\frac{2 \mathrm{Nry}_{i}}{\hat{\theta}_{\max }}$ \\
\hline \multirow{5}{*}{$\begin{array}{l}\text { 客 } \\
\text { 올 }\end{array}$} & $\mathrm{C} 63-42 \mathrm{H}$ & 10.81 & 18.22 & 15.47 & 27.65 & 13.52 & 21.63 & 18.10 & 30.92 \\
\hline & C63-41H & 18.89 & 26.83 & 24.43 & 45.95 & 21.31 & 37.77 & 27.19 & 48.86 \\
\hline & $\mathrm{C} 65-41 \mathrm{H}$ & 18.83 & 34.77 & 24.38 & 45.89 & 21.22 & 37.67 & 27.09 & 48.76 \\
\hline & $\mathrm{C83}-41 \mathrm{H}$ & 22.08 & 38.71 & 28.10 & 49.84 & 27.06 & 44.17 & 33.96 & 56.19 \\
\hline & C63-21H & 13.49 & 19.22 & 16.30 & 24.38 & 19.84 & 26.97 & 23.81 & 32.59 \\
\hline \multirow{5}{*}{ 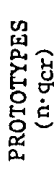 } & $\mathrm{C} 63-42 \mathrm{H}$ & 18.60 & 33.10 & 19.19 & 33.21 & 22.18 & 36.00 & 22.53 & 38.38 \\
\hline & $\mathrm{C} 63-41 \mathrm{H}$ & 20.35 & 33.91 & 23.69 & 42.84 & 24.11 & 40.71 & 27.01 & 47.39 \\
\hline & $\mathrm{C} 65-41 \mathrm{H}$ & 20.26 & 33.68 & 23.62 & 42.74 & 23.99 & 40.53 & 26.90 & 47.24 \\
\hline & $\mathrm{C83}-41 \mathrm{H}$ & 24.14 & 42.25 & 27.97 & 48.68 & 30.93 & 50.29 & 33.52 & 55.94 \\
\hline & C63-21H & 12.90 & 19.77 & 14.90 & 23.32 & 18.03 & 25.81 & 20.28 & 29.79 \\
\hline
\end{tabular}


Table 4 Mechanical properties of materials

\begin{tabular}{|c|c|c|c|c|c|}
\hline & \multicolumn{4}{|c|}{ Reinforcenent } & \multirow{2}{*}{ Concrete* } \\
\hline & $4.0 \phi$ & $3.2 \phi$ & $2.3 \phi$ & 1.00 & \\
\hline$\sigma_{y}$ & 4670.0 & 4860.0 & 3365.0 & 3150.0 & $F_{C}=351.6$ \\
\hline$E_{S}\left(x 10^{-1}\right)$ & 1.9 & 1.9 & 2.1 & 2.1 & $E_{C}=2.4 \times 10^{5}$ \\
\hline$\overline{\sigma_{u}}$ & 5990.0 & 6720.0 & 6730.0 & 5520.0 & $\cdots$ \\
\hline
\end{tabular}

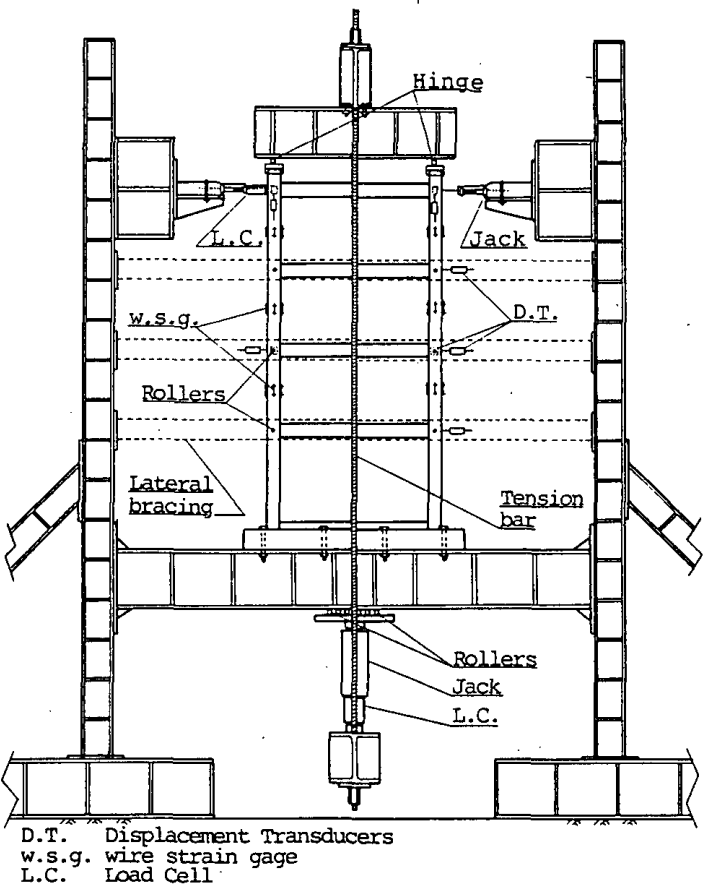

Table 5 Programme for horizontal loading

\begin{tabular}{|c|c|}
\hline $\begin{array}{c}\text { Cycle } \\
\text { No. }\end{array}$ & $\begin{array}{c}\text { Maximm total height-drift } \\
\delta_{\mathrm{H}} / \mathrm{H} \text { (percent) }\end{array}$ \\
\hline 1,2 & \pm 0.25 \\
\hline 3,4 & \pm 0.50 \\
\hline 5,6 & \pm 1.00 \\
\hline 7,8 & \pm 2.00 \\
\hline
\end{tabular}

Fig. 6 Setup for loading and measuring instruments

According to the Eq: ( 8 ) and Eq. (12), the vertical load carrying capacity of the models can be estimated to be nearly the same as that of prototypes except the $\mathrm{C} 63-42 \mathrm{H}$ type frame whose strength distributions were considerably changed between both the ones. It can also be seen from Table 3 that the effects of $K_{\theta i}$ value on the $n \cdot q_{c r}$ or $W_{c r}$ is much greater than those of the $\alpha_{v}$ values. The effects of the assumed deflected shape are not so great.

The mechanical properties of the materials used for the construction of these specimens are given in Table 4 .

Five specimens with its numbers ending with the alphabet "H" (e.g. C 63-41 H) were tested under displacement controlled reversed horizontal load, during which there was a previously applied constant vertical load $\left(\left\{W_{0} /\left(2 F_{c} b D\right)\right\}\right.$ $=0.2$ ) on the columns. At the end of last cycle of reversed horizontal loading, the vertical load on the columns was increased monotonically until the frame failed. The other three specimens with the alphabet ' $V$ ' in its numbers were tested only under monotonically increasing vertical load upto failure. Both the positive and negative horizontal loading were applied on the outer surface of the columns at the uppermost beam center level, while the two point vertical load was applied on the top of the two columns. Fig. 6 shows the setup for the test as well as the loading and measuring apparatus. The vertical loading apparatus was designed in such a way that the top of the specimens could move freely in its plane.

In aseismic design of buildings, story deflection is usually limited. The permissible interstory drift is prescribed to be 0.5 percent for moderate earthquakes in the Building Standard Laws of $\mathrm{Japan}^{8}$. However, it has been recognized that several times more interstory drift than 0.5 percent should be allowed for major earthquakes. In this programme, an ultimate total height drift $\left(\delta_{H} / H\right)$ induced by major earthquakes was assumed to be 2.0 percent. Table 5 shows the programme for the reversed horizontal loading.

\section{Test Results}

The load-deflection curves for reversed horizontal loading test of all the specimens are nearly similar. Upto the total height-drift of 0.5 percent, the hysteresis loops are spindle shaped. As the drift increases, the shape gradually changes into inverted $\mathrm{S}$ shaped ones, while the equivalent stiffness decreases. At the end of the last cycle of horizontal loading, the residual total height-drift was about 1.0 percent for all the specimens. Fig. 7 shows the $P$ - $\delta_{H}$ curves for two typical specimens. $W$ - $\delta_{H}$ curves for four different specimens are given in Fig. 8. One can readily compare the top displacement, $\delta_{\mathrm{H}}$, against the increasing vertical load, $W$, for the same type of specimen with or without the experience of reversed horizontal loading.

The crack patterns of four different specimens under different loading are given in Fig. 9. The crack patterns for horizontal loading of all the four-storied specimens are nearly similar, i. e., the cracks appeared mainly on the beams 

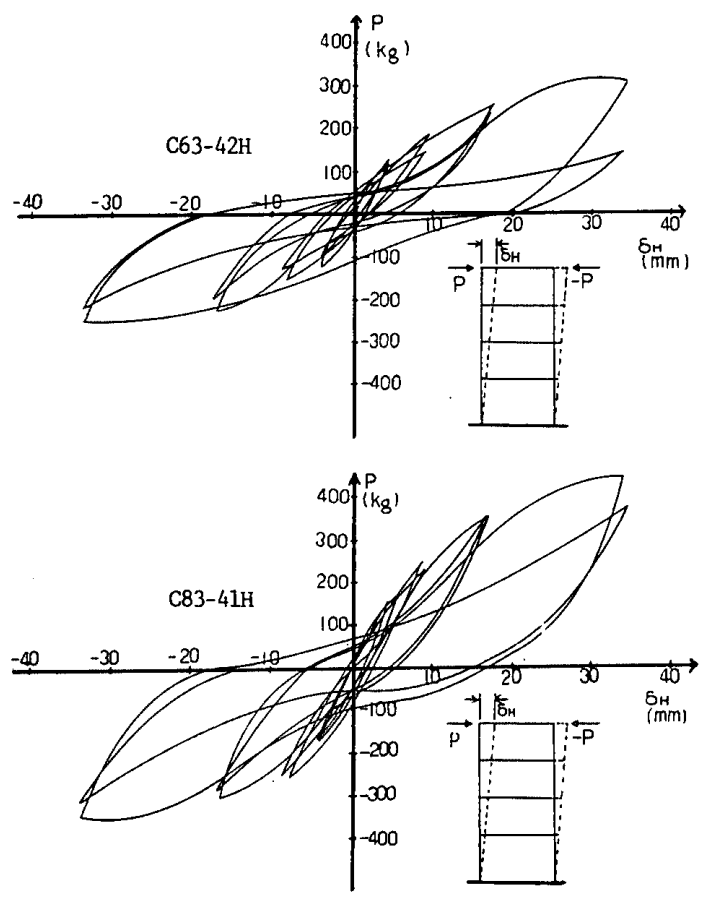

Fig. 7 Hysteresis loops under horizontal loading

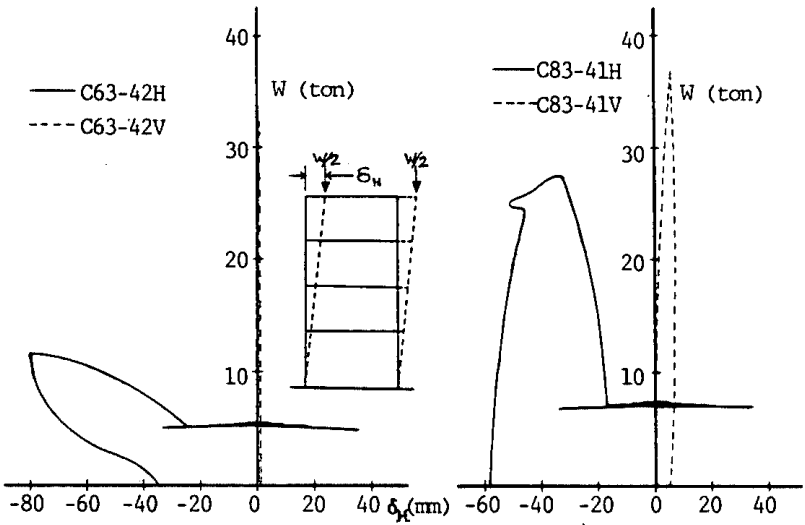

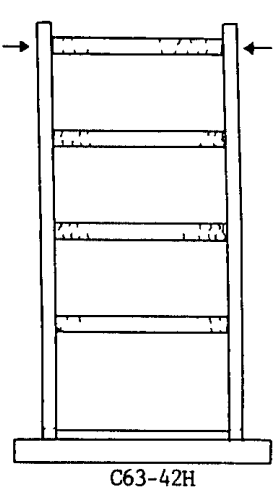

At the end of horizontal loading
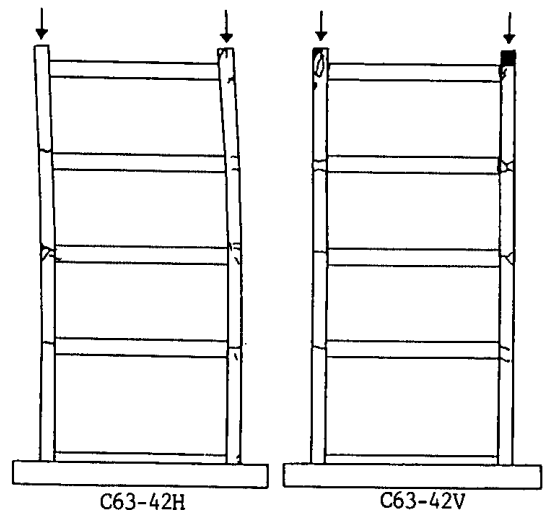

At the end of vertical loading

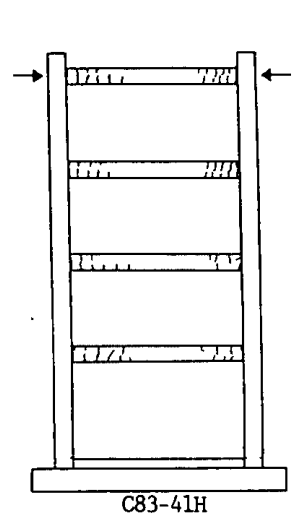

At the end of horizontal loading

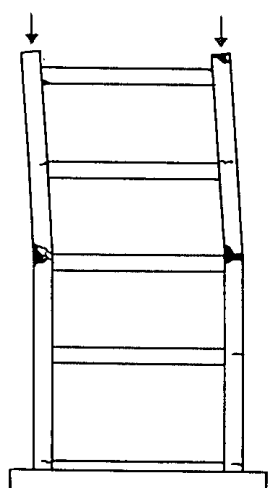

C83-41H

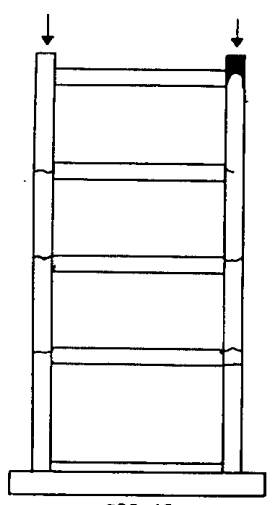

C83-41V

Fig. 9 Crack patterns under different loadings

Fig. 8 Load-deflection curves under vertical loading

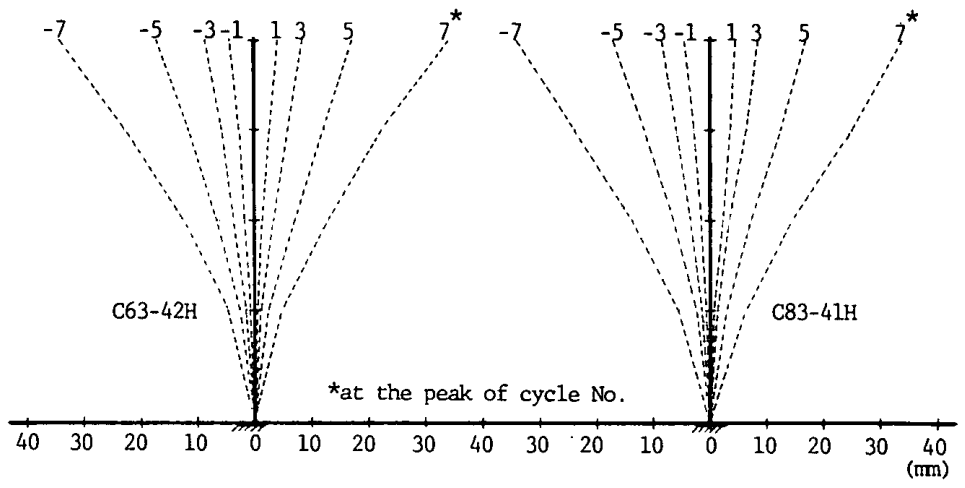

Fig. 10 Deflected shape under horizontal loading

with a very few cracks at the bottom of the columns, while the two-storied one had considerable cracks at the bottom of the columns as well as on the beams. The specimens with the experience of reversed horizontal loading, failed finally against the stability under monotonically increasing vertical load, while those without the experience of horizontal loading, failed under direct compression.

- All the five specimens show the similar deflected shape under reversed horizontal load. Each of the four-storied frames failed finally on the $3 \mathrm{rd}$ floor beam-column joint under its ultimate level of vertical load, while the 
Table 6 Experimented results of all the specimens

\begin{tabular}{|c|c|c|c|c|c|c|c|c|c|}
\hline \multirow{3}{*}{$\begin{array}{c}\text { Specimen } \\
\text { No. }\end{array}$} & \multicolumn{6}{|c|}{ For Horizontal Loading } & \multicolumn{3}{|c|}{ For Vertical Loading } \\
\hline & \multicolumn{3}{|c|}{$P_{u}(\mathrm{~kg})$} & \multicolumn{2}{|c|}{$\delta_{H_{u}}(\mathrm{~mm})$} & \multirow{2}{*}{$\begin{array}{l}{ }_{R} \hat{R}_{4} \\
(\mathrm{~mm})\end{array}$} & \multirow{2}{*}{$\begin{array}{c}\mathrm{w}_{\mathrm{L}} \\
\text { (tơn) } \\
\end{array}$} & \multirow{2}{*}{ 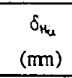 } & \multirow{2}{*}{$\begin{array}{r}{ }_{R}{ }^{\delta_{n}} \\
(\mathrm{~mm}) \\
\end{array}$} \\
\hline & Posi. & Nega. & ver. & Posi. & Nega. & & & & \\
\hline $3-$ & .302. & & 6.3 & 30.0 & 34.0 & -25.0 & 11.05 & -79.5 & -34.6 \\
\hline & & & & & 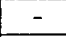 & & 7 & 0. & 1.5 \\
\hline $3-41$ & 5. & & 0.0 & 33.3 & 30.0 & -18.3 & 0.20 & 41.2 & $-48:$ \\
\hline $5-41$ & 0.0 & 280. & 0.0 & 32.0 & 28.0 & -20 & 47 & 38.7 & -30 \\
\hline $3-41$ & 450.0 & 362.5 & 406.3 & 30.0 & 30.0 & -17.3 & 27.36 & -32.0 & -58.8 \\
\hline & & & - & - & - & 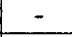 & 36.80 & 5.9 & 6.7 \\
\hline 215 & 2.5 & 300.0 & 366.3 & 18.0 & 18.0 & -6.8 & 20.85 & -17.9 & -17.9 \\
\hline $663-21 \mathrm{~V}$ & - & - & 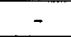 & - & - & - & 26.55 & 1.0 & \\
\hline
\end{tabular}

Table 7 Correlation of calculated and experimented values of horizontal load and the calculated values of the coefficients, $\alpha_{H}$ and $\beta$

\begin{tabular}{|l|c|c|c|c|c|}
\hline \multirow{2}{*}{ Specimen } & \multirow{2}{*}{$\alpha_{\mathrm{H}}$} & \multirow{2}{*}{$\beta$} & \multicolumn{3}{|c|}{$P_{\mathrm{U}}(\mathrm{kg})$} \\
\cline { 4 - 6 } & & & $\mathrm{Ca}$. & Exp. & Exp./Cal. \\
\hline $\mathrm{C} 63-42 \mathrm{H}$ & 0.40 & 0.93 & 244.0 & 276.3 & 1.13 \\
\hline $\mathrm{C} 63-42 \mathrm{H}$ & 0.33 & 1.00 & 284.0 & 300.0 & 1.06 \\
\hline $\mathrm{C} 65-41 \mathrm{H}$ & 0.53 & 0.80 & 304.0 & 290.0 & 0.95 \\
\hline $\mathrm{C} 83-41 \mathrm{H}$ & 0.34 & 0.99 & 336.0 & 406.3 & 1.21 \\
\hline $\mathrm{C} 63-21 \mathrm{H}$ & 0.33 & 1.00 & 334.0 & 366.3 & 1.10 \\
\hline
\end{tabular}

two-storied one failed at the 2 nd floor level. Fig. 10 shows the deflected shape of typical specimens under reversed horizontal loading. The overall results of all the specimens are listed in Table 6.

\section{Discussions}

i) Maximum strength under horizontal loading:

Table 7 shows the comparison between test results and calculated values for the maximum strength of five specimens under horizontal loads. This table also shows the values of the calculated equivalent flexural rigidity ratio $\alpha_{H}$ for columns of specimens. These calculated values were obtained by assuming the moment-curvature diagram for cross section of a column as shown in Fig. 11 and using the following two equations, by neglecting the variation of the axial forces induced in columns during horizontal loading.

$$
P_{u}=\frac{\sum_{i=1}^{n} M_{y i}+\beta M_{y}-W_{0} \delta_{H u}}{H}
$$

where $\beta M_{y}$ is the resisting moment at the bottom of the lowest column and $W_{0} \cdot \delta_{H u}$ is the effect due to eccentric vertical loading.

$$
\alpha_{H}=\frac{\delta_{e}}{\delta_{H u}}=\frac{\frac{P_{u} H^{3}}{3 E I}-\sum_{i=1}^{n} \frac{M_{y i} H_{i}}{E I} \cdot\left[\frac{H_{i}}{2}+H-H_{i}\right]}{\delta_{H u}}
$$

where $\delta_{e}$ is the elastic deflection of the cantilever when yield moment of beam is applied at each floor level in addition to the horizontal load.

In using these equations the relationship of $\alpha+\beta=4 / 3$ was used as shown in Fig. 11 by assuming that $M_{c} / M_{y}=1 / 3$ and $\phi_{c} / \phi_{y}=1 / 9$. The moment-curvature diagram in Fig. 11 were determined mainly for the simplicity of the relationship between $\alpha_{H}$ and $\beta$ but the curve in Fig. 11 is considered to represent basically the flexural properties of

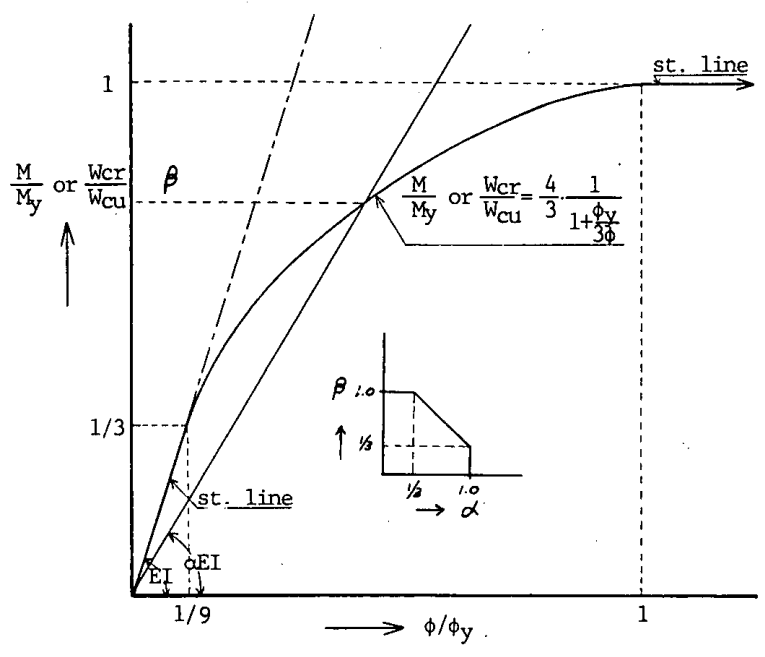

Fig. 11 The relationship between moment level or axial force level and the curvature of column cross section

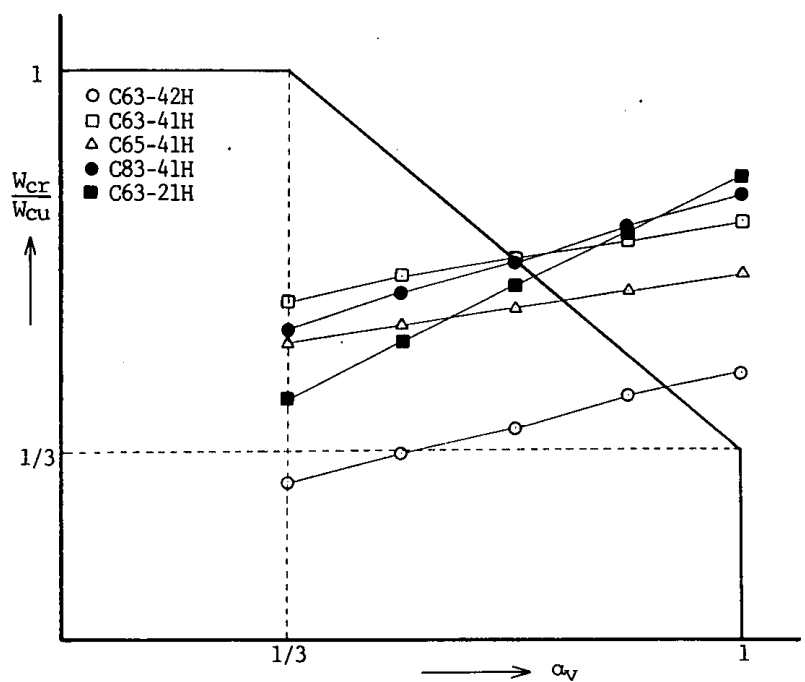

Fig. 12 Determination of the calculated values of $W_{c r}$ from the intersection between the curve by Eq. (12) and $W_{c r} /$ $W_{c u^{-}} \alpha_{v}$ curve 
the cross section of reinforced concrete columns.

The calculated values of $\alpha_{H}$ were $0.33 \sim 0.53$. This means that all the specimens except $\mathrm{C} 65-41 \mathrm{H}$ almost reach the strength at collapse mechanism $(\beta=1)$ of frames in calculations. It $c$ an be seen from Table 7 that the test values of maximum strength are a little higher than but nearly the same as calculated ones.

ii ) Veutical load carrying capacity:

The calculated values of vertical load carrying capacity were obtained by using Eq. (12) based on the following assumptions.

1) The top deflection is assumed the same with the maximum deflection under horizontal loading to determine the value of $\theta_{\max i}$. On the other hand the deflected shape along frame height is obtained by trial and errors so that it can be nearly the same as that selected as to make the critical load a minimum.

2) The equivalent flexural rigidity of the cross section of columns varies with the axial force level acting on the cross section, based on the relationship as shown in Fig. 11. It seems very difficult to obtain the exact values of equivalent flexural rigidity of the section at any level of axial force applied ${ }^{5)}$. Thus more practical method is adopted.

Fig. 12 shows the method of how to determine the vertical load carrying capacity, which is obtained as the intersection of the curve due to Eq. (12) and the assumed relationship between axial force level versus equivalent flexural rigidity ratio $\alpha_{v}$

It can be seen from Table 9 that test results are nearly the same as the calculated ones except the specimen $\mathrm{C} 63-42 \mathrm{H}, \mathrm{C} 65-41 \mathrm{H}$ and $\mathrm{V}$ specimens. The maximum top drift of $\mathrm{C} 63-42 \mathrm{H}$ specimen was by far greater under vertical loading with deflected shape of high order curve than that under horizontal loading. That means the values of rotation of upper beams go beyond the point A as shown in Fig. 2(b) and the equivalent stiffness becomes smaller than the assumed constant value upto point $A$. It seems due to the variation of beam strength along the height in this specimen. Thus, there is also a possiblity that the vertical load carrying capacity of the columns of actual frames in accordance with currently used methods is considerably lower than predicted by Eq. (8).

Table 9 also shows the values of $\alpha_{v}$ ranging from 0.66 to 0.88 , which are quite different from those of $\alpha_{H}$. Fig. 13

Table 9 Correlation of experimented and calculated ultimate vertical load carrying capacity and

Table 8 Assumed values of beam end rotation at total the calculated values of the coefficient, $\boldsymbol{\alpha}_{v}$ height-drift of $2 \%$ for calculation

\begin{tabular}{|c|c|c|c|c|c|}
\hline $\mathrm{n}$ & $i$ & $\begin{array}{c}x \\
(\mathrm{~cm})\end{array}$ & $\mathrm{x} / \mathrm{H}$ & $\begin{array}{l}{ }^{*} \theta_{\max } \\
\text { (rad). }\end{array}$ & $\begin{array}{l}\mathrm{s}^{\theta} \max \\
\text { (rad.) }\end{array}$ \\
\hline \multirow{4}{*}{4} & 4 & 170 & 1.00 & 0.0800 & 0.0400 \\
\hline & 3 & 130 & 0.77 & 0.0358 & 0.0306 \\
\hline & 2 & 90 & 0.53 & 0.0119 & 0.0212 \\
\hline & 1 & 50 & 0.29 & 0.0020 & 0.0118 \\
\hline \multirow[b]{2}{*}{2} & 2 & 90 & 1.00 & -- & 0.0400 \\
\hline & 1 & 50 & 0.55 & -- & 0.0222 \\
\hline
\end{tabular}

\begin{tabular}{|c|c|c|c|c|}
\cline { 3 - 5 } \multicolumn{2}{c|}{} & \multicolumn{3}{|c|}{ Vertical } \\
\hline Specimen & $a_{\mathrm{V}}$ & $\begin{array}{c}\text { Exp. } \\
\text { (ton) }\end{array}$ & $\begin{array}{c}\text { Cal. } \\
\text { (ton) }\end{array}$ & $\begin{array}{c}\text { Exp./Cal } \\
\text { (ratio) }\end{array}$ \\
\hline C63-42H & 0.88 & 11.05 & 13.83 & 0.80 \\
\hline C63-42V & -- & 32.27 & 31.15 & 1.03 \\
\hline C63-41H & 0.66 & 20.20 & 20.87 & 0.97 \\
\hline C65-41H & 0.73 & 18.47 & 21.73 & 0.85 \\
\hline C83-41H & 0.66 & 27.36 & 27.33 & 1.00 \\
\hline C83-41V & -- & 36.80 & 40.55 & 0.91 \\
\hline C63-21H & 0.69 & 20.85 & 19.94 & 1.04 \\
\hline C63-21V & -- & 26.55 & 31.45 & 0.85 \\
\hline
\end{tabular}

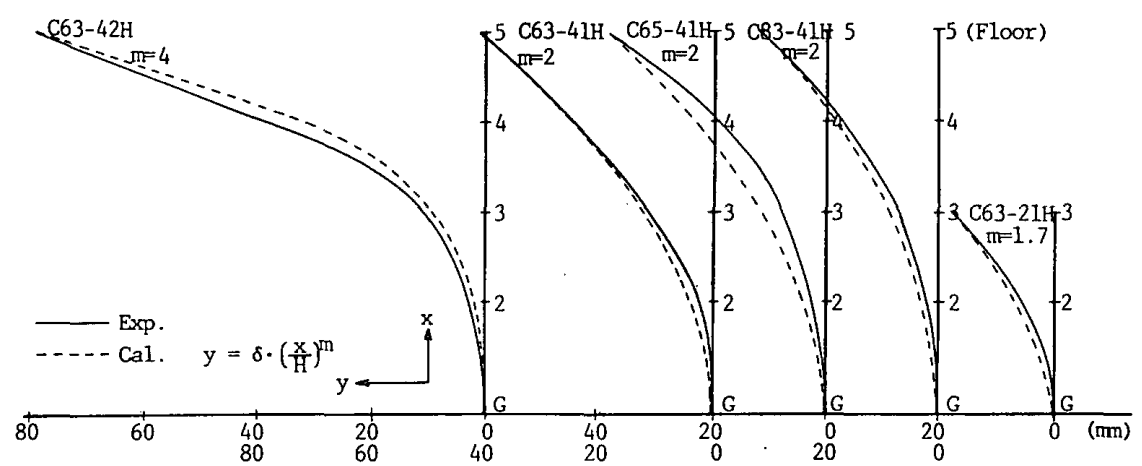

Fig. 13 Comparison of experimented and calculated horizontal deflections under maximum vertical load after horizontal loading 
shows the comparison of deflected shape at maximum vertical load between test results and calculated ones.

On the other hand the vertical load carrying capacity of columns of specimens C 83-41 V and C $63-21 \mathrm{~V}$ without the experience of horizontal loading is a little smaller than those calculated by Eq. (16). The vertical load carrying capacity decreased due to the local failure at the point of application of the load. Longitudinal reinforcement can also be judged to be ineffective for the values of $W_{c u}$ and also for those of $W_{c r}$ as shown for C $65-41 \mathrm{H}$ in Table 9.

\section{Conclusions}

Based on the study reported herein, the following conclusions may be made.

1) Simplified analytical method has been developed to evaluate the vertical load carrying capacity of the columns of the frames after subjected to reversed horizontal loads. This method was derived from the energy method based on the assumption that all the beam ends yield with rotational stiffness being the equivalent elastic one, while that the resistance of columns are determined from the assumed relationship between axial force level and the equivalent flexural rigidity ratio of the cross section.

2) Experimental works have been conducted to verify the validity of the above method. The number of specimen dealt with, totaled eight. Six were four-storied and the other two were two-storied frames. These model frames were subjected to concentrated vertical loads at the top of the columns, with or without the experience of horizontal loadings. This concentrated loading method was adopted from the simplicity of the application of loads, after establishing the relation between the models and the prototypes having distributed loads at every floor level, on the vertical load carrying capacity by using the above methods.

3) It has been found that the proposed method gives the good predictions of the vertical load carrying capacity $W_{c r}$ of the columns of multi-story weak-beam, strong-column frames with the experience of reversed horizontal loading upto post-yielding range. The values of $W_{c r}$ were about two-third of axial compression strength $W_{c u}$ as predicted for the frames in which strength of beams was arranged uniformly along the height, while was about one-third of $W_{c u}$, which was considerably smaller than predicted, for the frames in which strength of beams was allotted smaller for upper stories and greater for lower stories. Test results suggests that limit design method is superior to currently used method with respect to the safty against gravity load after major earthquakes.

4) Further study is needed to get general conclusions by adding experimental studies on statically determinate structure frames to the above experiments as well as by developing the more precise calculation methods.

\section{Acknowledgement}

This study has been conducted at the Structural Engineering Department of the University of Hiroshima. The authors would like to thank the assistance of the staffs, particularly Mr. H. Araki and Mr. E. Najima of the Earthquake Engineering Laboratory. The authors acknowledge the cooperation of S. Hayashi and H. Kawasaki, senior year students. The encouragements of Profs. Y. Mukudai and M. Hanai are also greatly appreciated.

\section{APPENDIX}

Reduction of Equations ( 8$) \sim(11)$

Assumptions :

1) $q_{1}=q_{2}=\cdots \cdots=q_{t}=\cdots \cdots=q_{n}=q_{c r}$

2) $H_{1}=H / n, H_{2}=2 H / n, \cdots \cdots, H_{t}=i H / n, \cdots \cdots, H_{n}=n H / n=H$

3) $y=\delta\left(\frac{x}{H}\right)^{m}$;

4) $y_{i}=\delta\left(\frac{H_{i}}{H}\right)^{m}$

5) $\theta=\frac{d y}{d x}=\frac{\delta m}{H}\left(\frac{x}{H}\right)^{m-1}$;

6) $\theta_{i}=\frac{\delta m}{H}\left(\frac{H_{i}}{H}\right)^{m-1}$

7) $M_{i}=K_{\theta i} \theta_{i}$

8) $(E I)_{e q}=\alpha_{v} E I$

$$
\begin{aligned}
U & =\frac{1}{2} \int_{0}^{H}(E I)_{e q}\left(\frac{d^{2} y}{d x^{2}}\right)^{2} d x \\
& =\frac{1}{2(E I)_{e q}} \int_{0}^{H}(M)^{2} d x
\end{aligned}
$$




$$
\begin{aligned}
& =\frac{1}{2(E I)_{e q}} \int_{0}^{H}\left\{\sum_{i}^{n} q_{i}\left(y_{i}-y\right)-\sum_{i}^{n} K_{\theta i} \theta_{l}\right\}^{2} d x \\
& =\frac{1}{2(E I)_{e q}} \int_{0}^{H}\left[\left\{\sum_{i}^{n} q_{i}\left(y_{t}-y\right)\right\}^{2}-2 \sum_{i}^{n} q_{i}\left(y_{t}-y\right) \sum_{i}^{n} K_{\theta i} \theta_{t}+\left(\sum_{i}^{n} K_{\theta l} \theta_{t}\right)^{2}\right] \\
& =\frac{1}{2(E I)_{e q}} \int_{0}^{H}\left[q_{c r}^{2}\left\{\sum_{i}^{n}\left(y_{i}-y\right)\right\}^{2}-2 q_{c r} \sum_{i}^{n}\left(y_{i}-y\right) \sum_{i}^{n} K_{\theta i} \theta_{i}+\left(\sum_{i}^{n} K_{\theta i} \theta_{i}\right)^{2}\right] \\
& =a^{\prime} q_{c r}^{2}+b^{\prime} q_{c r}+c^{\prime} \\
& U_{1}=\frac{1}{2} \int_{0}^{H} \sum_{i}^{n} q_{i}\left(\frac{d y}{d x}\right)^{2} d x+\frac{1}{2} \sum_{i=1}^{n} M_{i} \theta_{i} \\
& =\frac{n}{2} q_{c r} \int_{0}^{H}\left(\frac{d y}{d x}\right)^{2} d x+\frac{1}{2} \sum_{i=1}^{n} M_{i} \theta_{l} \\
& =b^{\prime \prime} q_{c r}+c^{\prime \prime} \\
& \because U=U_{1} \text {, hence } \\
& a=a^{\prime} \cdots \cdots \cdots \cdot E_{q} .(9) \\
& b=b^{\prime}-b^{\prime \prime} \cdots \cdots \cdots \cdot E_{\mathrm{q} .} \text { (10) } \\
& c=c^{\prime}-c^{\prime \prime} \cdots \cdots \cdots \cdot E_{q .} \text { (11) }
\end{aligned}
$$

An example of the above integrations as below:

$\int_{0}^{H} \sum_{i}^{n} y_{i} d x=\int_{0}^{H_{1}} \sum_{i=1}^{n} y_{i} d x+\int_{H_{1}}^{H_{2}} \sum_{i=2}^{n} y_{i} d x+\cdots \cdots+\int_{H_{n-1}}^{H_{n}} \sum_{i=n}^{n} y_{i} d x$

Notations

$A_{c}$ : area of concrete

$A_{s}:$ total area of reinforcement

$A_{\mathrm{t}}$ : area of tensile reinforcement

$b$ : width of cross section

$D:$ depth of cross section

$d$ : depth of center of tensile reinforcement from maximum compressed fibre

$E_{c}$ : Young's modulus of concrete

$E I$ : elastic flexural rigidity of cross section of column

$E I_{x}$ : varying flexural rigidity of cross section of column

$(E I)_{e q}$ : equivalent flexural rigidity of cross section of column

$E_{s}$ : Young's modulus of steel

$F_{c}$ : maximum compression strength in concrete

$H$ : height of frame from top of the foundation to the uppermost beam level

$H_{i}$ : height of frame from top of the foundation to the ith beam level

$i$ : story number, $1 \sim 4$

$j$ : story number, $1 \sim 4$

$K_{\theta i}$ : equivalent rotational stiffness at beam end

$l$ : length of beam from axis to axis of columns

$M_{c}$ : cracking moment of column

$M_{i}$ : bending moment of beam

$M_{y}:$ yeild moment of column

$M_{y i}$ : yeild moment of beam

$m:$ constant, used in shape function of column

$n:$ total number of stories

$P$ : horizontal load

$P_{u}$ : ultimate horizontal load

$q_{c r}$ : calculated critical vertical load at every beam-column joints

$q_{i}$ : vertical load on column from beams

$U$ : strain energy of bending of column

$U_{1}$ : decrease in potential energy due to lowering of the point of application of vertical load 
$\dot{W}:$ vertical load

$W_{0}$ : working vertical load on columns during horizontal loading

$W_{c r}$ : calculated critical vertical load

$W_{c u}$ : calculated cumulative vertical load

$W_{u}:$ measured ultimate vertical load

$x:$ an arbitrary distance along the height of frame from the top of the foundation

$y$ : horizontal displacement of frame at the height of $\mathrm{x}$

$\Delta_{1} \sim \Delta_{k}:$ constants, used in the Fourer Series of shape function

$\alpha$ : flexural rigidity reduction ratio of cross section of column

$\alpha_{H}$ : flexural rigidity reduction ratio of cross section of column during horizontal loading

$\alpha_{v}$ : flexural rigidity reduction ratio of cross section of column during vertical loading.

$\beta$ : moment reduction ratio of column

$\delta:$ horizontal displacement at the uppermost beam level for analysis under vertical load

$\delta_{e}:$ horizontal displacement at the uppermost beam level for elastic analysis under horizontal loading

$\delta_{H}$ : measured horizontal displacement at the uppermost beam level

${ }_{R} \delta_{H}$ : residual horizontal displacement at the uppermost beam level at the end of horizontal or vertical loading

$\delta_{H u}$ : horizontal displacement at the uppermost beam level at the ultimate stage of horizontal or vertical loading

$\delta_{H i}$ : horizontal displacement at the ith beam level for analysis under vertical load

$\phi_{c}$ : curvature at cracking of column section

$\phi_{y}:$ curvature at yielding of column section

$\sigma_{u}:$ maximum strength of reinforcement

$\sigma_{y}:$ yield strength of reinforcement

$\theta_{t}:$ rotation at beam end

$\theta_{\max i}:$ maximum rotation at beam end under horizontal load

\section{REFERENCES}

1) American Cocrete Institute: "Symposium on Reinforced Concrete Columns", ACI Publication SP-13, pp. 55 156, 1966

2) Ford, J.S., Chang, D. C. and Breen, J.E. : "Behavior of Concrete Columns Under Controlled Lateral Deformation", Journal of the ACI, Proceedings V.78, January-February 1981/No. 1, pp. 3 20

3) Ford, J.S., Chang, D. C. and Breen, J. E. : "Behavior of Unbraced Multipanel Concrete Frames", Journal of the ACI, Proceedings V.78, March-April 1981/No.2, pp. 99-115

4) Mohit, S. M. P. and Shimazu, T. : "The Vertical Load Carrying Capacity of the Columns of Multi-Story Frames with the Experience of Horizontal Loading", Reprint of Chugoku Meeting of Architectural lnstitute of Japan, March, 1985, Vol. 12, pp. $113 \sim 116$

5) Timoshenko, S.P. and Gere, J. M. : “Theory of Elastic Stability”, McGraw-Hill International Book Company, Second Edition, 1982, pp. 82 162, 163 211

6) Architectural Institute of Japan : “AIJ Standard for Structural Calculation of Reinforced Concrete Structures”, 1982, pp. 213 (in Japanese edition)

7) Muto, K. : "Plastic Design of Reinforced Concrete Structures", Part 2 in Earthquake Resistant Design Series, Maruzen Co. Ltd., pp. 84 292

8) Ministry of Construction, Japan: “Building Standard Law Enforcement Order”, 1981, Chapter III, Section 8, Article 82-2 


\title{
水平荷重をうけた多層鉄筋コンクリートフレーム柱の鉛直耐力（梗概）
}

\author{
正会員嶋 津 孝 之* \\ 正会員 S.M. Parvez Mohit**
}

最近，鉄筋コンクリート建物の耐震設計の基本理念と して,フレームをはり降伏型に設計する考えが採用され てきている。地震時の水平応答変位を各層に分散させる ことを目的としたものであるが，鉄筋コンクリートはり は，基本的に原点指向の特徵をもつ剛性低下型の復元力 特性を有している。したがって，はり降伏型フレームは 地震を経験することによって，地震後，たとえ外観上は 元にもどっても，はり端部に剛性低下域が生ずることに なる。このようなフレームは, 地震後の鉛直方向の抵抗 性に関して，2つの問題を有していると考えられる。一 つは，はり端部に剛性低下域が生じることによって，連 層にわたる柱の鉛直荷重に対する安定性が低下する恐れ があることである。今一つの問題は，はりそのものの鉛 直荷重に対する抵抗性能の問題である。

本論文は，前者の問題をとりあげ，実施した実験的研 究を報告するものである。特に, 動的解析等からも相対 的に大きな地震力をうけることが明らかになっている中 低層建物のフレームを対象としている。

本論文では，ます，実験現象を追跡するために必要な 理論式の誘導を行っている。大変形に至る正負繰返し水 平荷重をうけた連層柱の鉛直耐力を求める方法をのべた ものである。各層のはり端が降伏し，その位置に等価線 形回転バネが存在するとし, 一方, 柱は一様断面で, や はり等価断面剛性を有する弾性体として圾っている。こ のような仮定に基づいて, エネルギー法(式 (1)〜 ( 3 )) を用いると，残る問題は座屈モードをどう仮定するかで ある。一般的な表現としては，式（6）の級数を用いる ことになる。しかし，この式を高次不静定フレームに用 いる場合には，きわめて繁雑な計算を必要とする。本論 文では, 水平荷重をうけたフレームを対象にしているこ とから，鈶直荷重に対する座屈モードが1次モードにな ることを考虑して, 式 ( 7 ) の形状のモードを仮定した。 この場合には, この式を式（3）に代入して, 座屈荷重 が最小となる $m$ を求め机ばよい。さて, 現実の建物に おいては, 柱には, 各層ごとに, はりから力が伝ってゆ

*広島大学 教授.工博

**広島大学 大学院生.Mr. of Eng. (昭和 60 年 3 月 11 日原稿受理)
くが，かりに，柱には，層ごとに等荷重が加わり，かつ 各層高が等しいとすると, そのときの連層柱の鉛直耐力 は式（８）によって求めることができる。また，次節で のべる実験的研究において実施したように，柱への鉛直 荷重を，連層柱の頂部への集中荷重に置きかえた場合の 鉛直耐力は式 (12)によって求めることができる。一方, 水平荷重をうけていない場合には，柱の珐縮耐力できま るので, 式（16）を用いることができる。

このような理論式の有効性をみるために，4層および 2 層の小型フレームを用いた実験を行った。基準試験体 は図 3 に示す一文字型の 1 スパン建物を想定し，その 1 フレームをきり出したもので, 水平保有耐力計算值はフ レーム ( 6 層) だけでは, 相当重量に対し，0.09であり， 耐震壁と併わせて, 建物全体としての耐震性能目標を 0.30 としている。試験体は全部で 8 体であり, うち 5 体は，水平荷重を加えたあとに，鉛直耐力を調べた。ほ かの 3 体は，直接，鉛直耐力だけをみたものである。ま た 8 体のうち 6 体は 4 層で, 2 体は 2 層であるが, 図 4 に示す理由で，それぞれ 6 層および 3 層を表している。 また高さ方向に，はりの主筋量を変化させたものと，主 筋量の総和は同じで, 各層はりに均等配分した, 極限設 計の立場から設計した試験体とがある。表 1 に各試験体 の詳細を示す。さて, 上記の水平荷重後の鉛直耐力検討 用 4 層および 2 層試験体と原型の 6 層および 3 層骨組に ついて式（12）および式（8）を用いて, 各変数に $2 つ$ の値を与え求めた耐力計算値を比較したのが, 表 3 であ る。C 63-42 H 試験体を除いて, 試験体と原型とが, ほ ぼ似かよった值になることがわかる。またこの表から， はり端バネ威性 $K_{\theta i}$ の値が, 連層柱の鉛直耐力に最も大 きな影響力をもっていることがわかる。次に柱の等価剛 性 $\alpha_{v}$ の値が影響力をもち, 最後にたわみ形状である。

加力測定の様子を図 6 に示す。水平荷重は正負等振幅 の繰返し加力で, そのプログラムを表 5 に示す。頂部最 大移動率が $2 \times 10^{-2} \mathrm{rad}$. になるまで水平荷重を加え, そのあと, 鉛直耐力を調べた。実験結果は表 6,7 およ び 9, 図7 10 および 13 に示すとおりである。

実験結果を要約すると, まず, 水平荷重時においては 頂部最大移動率 $2 \times 10^{-2} \mathrm{rad}$. での耐力を実験値と計算 
值を比較したところろ, 表 7 に示すように，ほぼ一致した 結果がえられた。ここに計算値とは, はりはすべて降伏 していると仮定し，1 層柱脚の剛性低下率を考慮したも のである。柱断面の曲げモーメント一曲率曲線を図 11 に仮定し，式（17）（18）を用いて求めた。表 7 に示す ように, 剛性低下率 $\alpha_{H}$ は 0.33 0.53であり, 柱脚も, 大体降伏耐力に達して, ほぼ崩壊時の耐力計算値といえ る。一方，鉛直荷重に対する耐力について，実験值と計 算值を比較したのが，表 9 である。計算値の方は，次の 仮定のもとに, 式 (12) を用いて求めたものである。i ) 各層はりの等価線形バネ㴊性は, 水平荷重時の頂部最大 変位に基づいて求める。ただし,たわみ形状は, 式（7） の $m$ が最小值をとるときの形状になるよう, 試行錯誤 によって求める。

ii）柱断面に, 軸力が加わってゆく場合の断面の曲 げ剛性は図 11 の曲線に従うものとする。図 12 は, 最終
的に計算値がえられる様子を示したものである。さて， 表 9 から明らかなように, C 63-42 H 試験体を除いて, 実験値と計算値は，ほぼ一致しているといえる。C 63-42 H は, 最大耐力時に, 頂部水平変形が著しく増加 し, 水平荷重時の最大変位を大幅に越えた。上層のはり の等価剛性が計算仮定の值より，相当低下していること が考えられる。以上より，弾性応力分布に基ついた，現 行設計法のように，上層ほど，はりの抵抗を小さくする 場合には, ·水平荷重をうけたあとの連層柱の鉛直耐力は 小さくなることが予想され，極限設計法の開発が望まれ ることがわかった。なお，鉛直耐力計算值を求める際に えられた柱の剛性低下率 $\alpha_{v}$ は 0.66 0.89であり，水平 荷重時の $\alpha_{H}$ とかなり違った値になる。最後に，図 13 に おいて, 最大耐力時の坐屈モードを，ほぼ予測できるこ とを示した。 